\title{
Una versión judeoespañola de Los relatos de Ben-Sirá según un manuscrito de la Guenizá de El Cairo
}

Elena ROMERO

CSIC, Madrid

\section{INTRODUCCIÓN}

En otro lugar me he ocupado de las versiones judeoespañolas de la obra narrativa hebrea comúnmente llamada Alfabeta de Ben$S_{i r a}{ }^{1}$ y con mayor propiedad Los relatos de Ben-Sirá, redactada, según la opinión de la moderna investigación, hacia finales del siglo IX o principios del X, toda ella en Bagdad o en Bagdad sólo una parte y la otra en el norte de África o en el sur de Italia ${ }^{2}$.

Conviene recordar su contenido. El texto transmitido y fijado por la imprenta a partir de la primera edición de Constantinopla 1519 (ó 1514) ${ }^{3}$ consta de dos partes, (A) la Semblanza de Ben-Sirá

\footnotetext{
${ }^{1}$ Vid. mi artículo "Versiones judeoespañolas del libro hebreo medieval Los relatos de Ben Sirá", en History and Creativity, eds. Tamar Alexander et al. (Jerusalén 1994) págs. 177-187.

${ }^{2}$ Sobre el texto y su transmisión puede verse el exhaustivo estudio de Eli YAssif, The Tales of Ben Sira in the Middle-Ages, A Critical Text and Literary Studies (Jerusalén 1984) [en hebreo], cuya bibliografía de págs. 191-194 me exime aquí de repeticiones ociosas. Debo añadir sin embargo la reseña al libro publicada por Yosef DAN, "Mehcar hadáš 'al sipuré Ben-Sirá", Kiryat Sefer 1-2 (1986) págs. 294-297.

${ }^{3}$ De la fecha de la primera edición se ocupa Yassif Ben Sira págs. 189-190. M. SteinsCheneider, en su libro Alphabetum Siracidis (Berlín 1858), publicó el texto de la segunda edición de Venecia 1544 con variantes procedentes de un manuscrito de Leyden; vid. M. STEInSCHeneider, Catalogus Codicum Hebraeorum Bibliothecae Academiae Lugduno-Batavae (Lugduni-Batavorum 1858) núm. 59, págs. 264-270: págs. 266-268.
} 
y (B) la Alfabeta de Ben-Sirá. La primera (A) puede dividirse en cinco segmentos: 1) nacimiento de Ben-Sirá; 2) su diálogo con el maestro, que incluye veintidós consejos del prodigioso discípulo, iniciados con las sucesivas letras del alefato; 3) los estudios de Ben-Sirá; 4) Ben-Sirá y los sabios de Nabucodonosor; y 5) las veintidós preguntas de Nabucodonosor a Ben-Sirá. En cuanto a la (B) Alfabeta consta de veintidós proverbios arameos que comienzan con las sucesivas letras del alefato, a cada uno de los cuales sigue un comentario en hebreo más o menos alusivo al contenido del proverbio ${ }^{4}$.

Conocemos cuatro versiones judeoespañolas: una manuscrita parcial, procedente de la Guenizá de El Cairo, publicada hace ya cerca de noventa años por M. Schwab ${ }^{5}$; y tres ediciones, dos completas de Constantinopla 1823 y Salónica 1859, y una parcial que sólo contiene la (B) Alfabeta, incluida entre las adiciones tras el texto del Me ám lo é $z$ de Josué en la edición de Salónica 1867.

Voy a ocuparme aquí de reeditar y analizar la primera versión mencionada, la manuscrita procedente de la Guenizá, que parece ser la más antigua que conocemos. Y ello por dos razones: primero, porque como ya advertía en mi citado artículo ${ }^{6}$, la edición de Schwab es desastrosa y sus lecturas del texto aljamiado están plagadas de errores e invenciones que lo dejan ininteligible; y segunda, porque el editor omitió la transcripción de la última hoja, indicando que "le feuillet 131 est trop déchiré pour pouvoir être lu avec suite" ${ }^{7}$.

El manuscrito se conserva hoy en la biblioteca de la Alliance Israélite Universelle (núm. IX.B 6$)^{8}$ y consta de 6 hojas en cuarto, que están numeradas en recto de los folios las tres primeras 129 -

${ }^{4}$ Sobre las fuentes de los proverbios puede verse el artículo de Israel LÉvI, "Les deux Alphabets de Ben Sira", REJ 53 (1907) págs. 62-66; y las correspondientes notas de Yassif Ben Sira págs. 261-283.

5 En su artículo "Version espagnole des Alphabets de Ben-Sira", en REJ 54 (1907) págs. 107-112; vid. también allí los comentarios y correcciones de S. Poznanski en "La version espagnole des Alphabets de Ben Sira" (págs. 279-280).

' ROMERo "Ben Sirá" pág. 180 y nota 7.

7 Schwab "Alphabets" pág. 107.

${ }^{8}$ Collection de fragments de la Guenizah du Caire, Consistoire de Paris, depositado en la biblioteca de la Alliance Israélite Universelle. Quiero expresar aquí mi agradecimiento a $G$. Weil, conservador de la Biblioteca y Archivos de l'Alliance Israélite Universelle, quien en 1988 me autorizó a la consulta y estudio del texto; a Mme. Yvonne Levine, quien con su proverbial eficacia me atendió en mi posterior viaje a París para consultar directamente el manuscrito; y a Jean-Claude Kuperminc, actual conservador de dicha institución, quien me ha autorizado a reproducir aquí dos folios del manuscrito que edito. 
131 en caracteres hebreos, las dos últimas 141-142 en números arábigos, y sin numerar una hoja tras la 131; una mano posterior ha numerado en arábigos la parte inferior de las hojas, dándole al manuscrito una ordenación disparatada ${ }^{9}$.

El texto que edito ocupa completos los folios 129-131; los restantes contienen una versión muy fragmentaria de las coplas de Las hazañas de José, del coplero sefardí Abraham Toledo, que vieron la luz por primera vez en Constantinopla $1732^{10}$.

Del largo texto de Los relatos de Ben-Sirá sólo figuran en el manuscrito de París unos pocos fragmentos. De la (A) Semblanza, el final del (A.2) diálogo entre Ben-Sirá y el maestro, que corresponde a los consejos que se inician con las letras cof a tav (h. 129a) ${ }^{11}$, los pasajes donde se cuentan (A.3) los estudios de Ben-Sirá, (A.4) la maquinación que urden contra él los sabios de Nabucodonosor (130b-131b) y (A.5) las tres primeras preguntas del rey (131b). Entre ambos fragmentos -el final del diálogo con el maestro y los estudios- en medio de una página y precedida por un epígrafe centrado aparece intercalada la (B) Alfabeta de Ben-Sirá (129a-130a), en la que sólo constan los proverbios arameos y su traducción al judeoespañol.

\section{EDICIÓN DEL TEXTO ${ }^{12}$}

\section{[A. Semblanza de Ben-Sirá]}

\section{[A.2. Consejos de Ben-Sirá a su maestro (final)]}

1129a_Quené a ti haćienda y mujer buena y muchiguarás hijos 'hajamim.

${ }^{9}$ He aquí las equivalencias de esa nueva numeración con la antigua: $1=129$, $2=130,3=141,4=142,5=$ hoja sin numerar y $6=131$.

${ }^{10}$ Vid. Elena Romero et al., Bibliografía analítica de ediciones de coplas sefardies (Madrid 1992) núm. 4 y la bibliografía allí anotada.

${ }^{11}$ A partir de ahora, en los números entre paréntesis, que indican la(s) hoja(s) y que pueden ir seguidos (tras dos puntos) de la precisión de las líneas, se prescinde de la abreviación de h./hs.

${ }_{12}$ Indico las páginas mediante numeración volada en negrita y precedida de barra; mediante barra volada señalo las líneas del original, que numero de cinco en cinco. Entre corchetes indico las correcciones y suplo, cuando puedo, los pasajes ilegibles; las letras escritas sobre la línea las indico entre ángulos $<>$. Para facilitar la remisión, numero los proverbios de la Alfabeta. Al final del texto explico las palabras que puedan ser de difícil comprensión. 
Díjole:

-Di reš.

Díjole:

'-Rehoc de većino malo, que sus pies para mal coren [cf. Is 59.7], y sé [tú] 'amigo con ellos y dales de tu comida para ${ }^{15}$ que alguna vez si te alevantan alguna 'alilá, que den "edut bueno por ti.

Díjole:

-Di šin.

Díjole:

'-Šmá, mi señor, a mis dichas y acosta tus orejas 'y sey honesto a tu haber y alguna cośa 'mala no la quites por tu boca.

Díjole:

-Di tav.

Díjole:

10-Ticné a ti ducados. Si tienes munchos ducados no se 'lo digas a tu mujer afilú que sabes que es 'muy hermośa y buena.

Díjole el hajam:

-Sobre ti se 'demudaron sidré berešit.

Díjole Ben-Sirá:

-En kol hadáš [Ecl 1.9, 'No hay nada nuevo (bajo el sol)']. 'Ves aquí Yirmiyahu que le anveźó a Baruj ben Neriyá y le dijo: ${ }^{115}$ "Di álef» y dijo "Ejá" [Lam 1.1, ‘Cómo ...']; díjole: «Di bet", dijo "Bajó tibké" [Lam 1.2, lit. 'Llorar llorarás'] ${ }^{13}$.

'[B.] Alfabeta SEgunda de BeN-SirÁ

[1] Quere dećir: Honra 'al médico antes que lo haiga de menester.

[2] בר דלא בר שבתיא על אפי מיא ויטות'Quere dećir: ${ }^{120}$ Hijo que no es bueno échalo sobre faces de las 'aguas.

[3] גרמא דנפיל בחולקך גרדיה Quere dećir: Güeso que 'te cayó en parte ráetelo con arte ${ }^{14}$.

${ }^{13}$ Alude el texto a la narración de Jeremías 36.1-4. La identificación del rollo (hb. meguilá) al que allí se alude con el libro de Lamentaciones (hb. Ejá), cuyos cuatro primeros capítulos se organizan en series con acróstico alefático, la encontramos en TB-Mo ed Catán 26a. Vid. bibliografía en YASSIF Ben Sira pág. $212(1)$.

${ }^{14} \mathrm{O}$ lo que es lo mismo, aprovecha lo que tienes. 


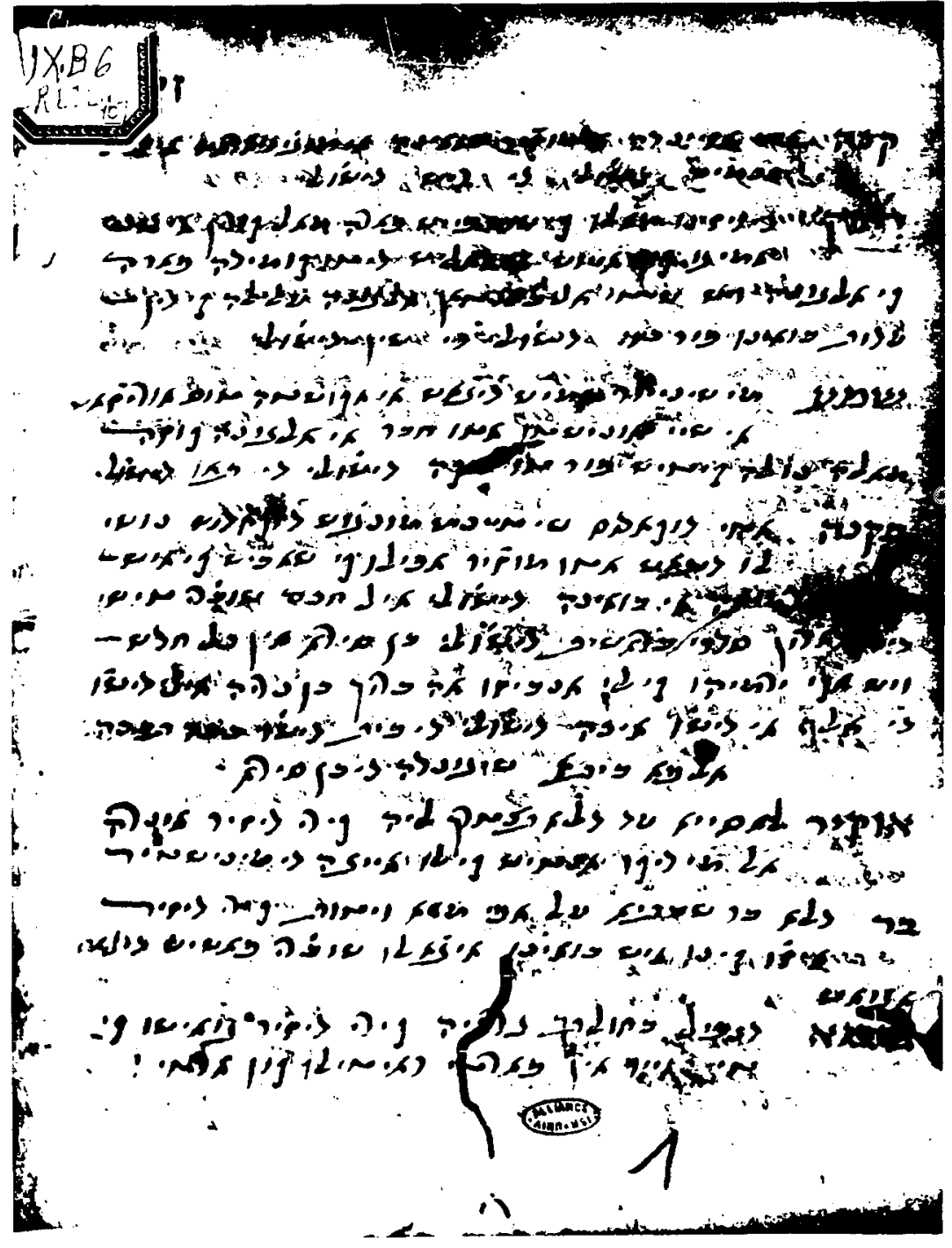

AIU, Ms. IX.B 6, fol. 129a 


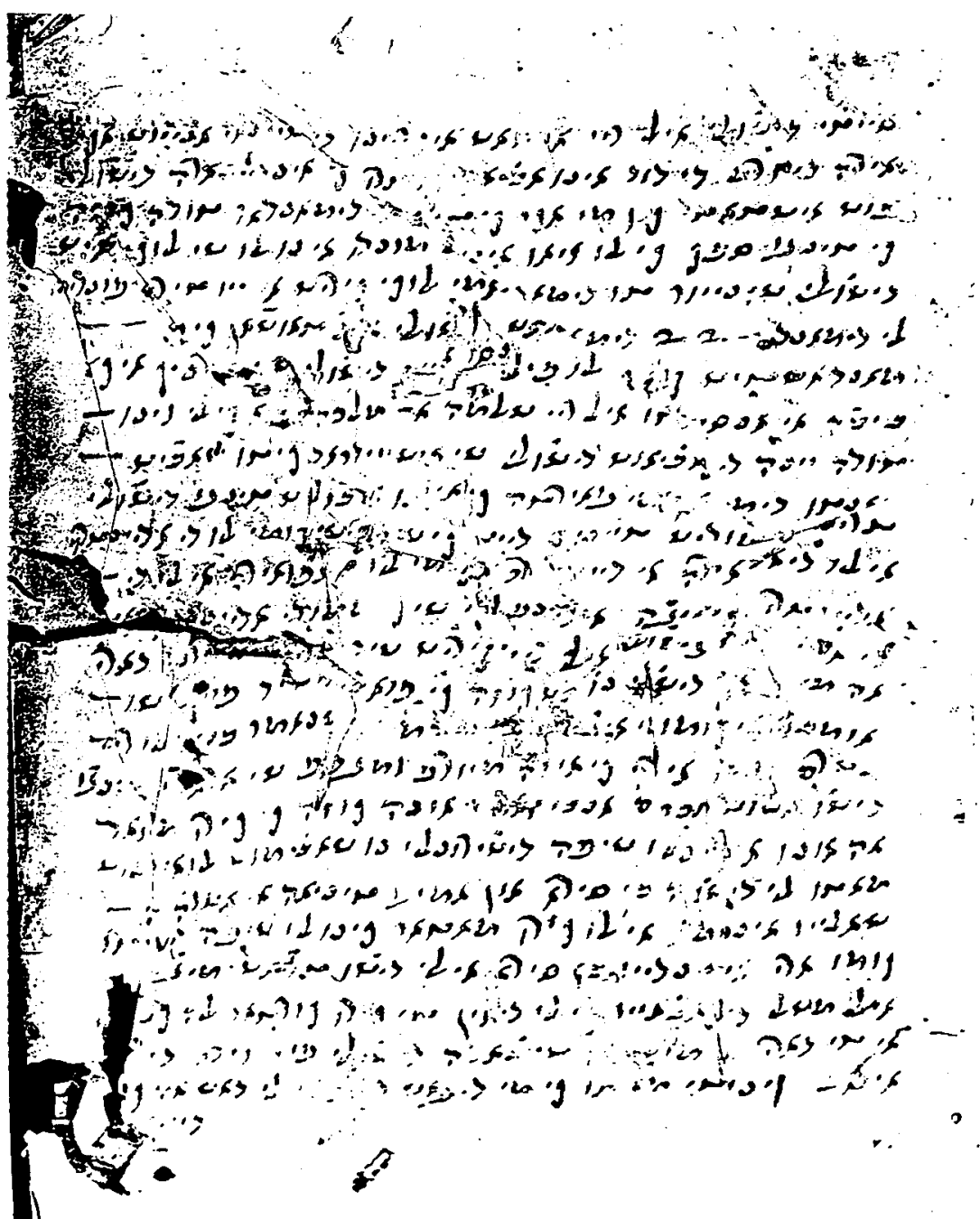

AIU, Ms. IX.B 6, fol. 131b 
[4] ${ }^{129 b /}$ Quere dećir: 'El oro quere majado y el muchacho quere harbado.

'הוי טב וידך מן טבתא לא תמנע [5] Quere dećir: Sey bueno 'y tu mano del bien no te vedes.

[6] y guay del que se apega con él.

[7] 'ירוק לחמך על אפי מיא ואת משכח ליה בסוף יומאיא del que echaba el pan a la mar.

[חזית חמר אוכס לא אוכס ולא חיור [8uere decir: ¿Vistes ${ }^{110}$ al aśno? Ni negro ni blanco.

[9] לביש לא תעביד ובישא לא מטי לך [9 Q no hagas y no te verná mal a [ti]. 'Como el ma'asé del que aỵidiguó al león.

'ידך מן טבותא לא תמנע [10] Quere dećir: Tu mano no vedes ${ }^{1 / 5} \mathrm{de}$ haćer bien a buenos.

בלתא עלתא לגיננא ולא ידע מה מטי לה [11' Quere dećir: 'La novia sube del tálamo y no sabe lo 'que le verná.

[12 'לחכמייא ברמיזא לשטייא בקורמתא Q Q cencias y al loco con palo.

[13 [מקיר מבסרוה דומי לחמרא Quere dećir: El que honra 'al malo asemeja al aśno.

[14 ${ }^{130 a}$ Quere dećir: Fuego 'encendido asegas munchas quema.

[15] סב בביתא סימנא טבא בביתא Quere dećir: Viejo en 'caśa hallen [?] bien en la caśa.

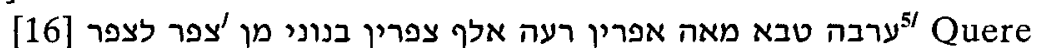
dećir: Fianza buena, 'cien [tachado mayorales] mañanas; la mala, mil mañanas; 'la mediana, de una mañana a la otra mañana ${ }^{15}$.

פתור פתורא פרש מן לוק[] [17' Quere dećir: Ves pelear, ${ }^{\prime 10}$ pon la meśa y se corta.

[18] 'צריך אתה למיסב ולמתן יהב חולתך עם בה טביין 'Quere dećir: Queres dar y tomar, ajuntate con 'buenos.

[19] Qקריבא סחורתא אכלתיא מריא Quere dećir: Cercana ${ }^{115} \mathrm{mi}$ mercadería la como su patrón.

]20] רחימא קדמאה לית את הפר ביה Q no niegues en él.

[21 'שיתין מלכין ירבין לך ומלכות נפשיך לא תשב[ו]ת 'Quere dećir: Setenta consejos si te dan, ${ }^{120}$ el tuyo $n[o$ de]jes de haćer.

\footnotetext{
${ }^{15}$ Quiere decir que en cualquier caso es malo salir fiador por alguien.
} 


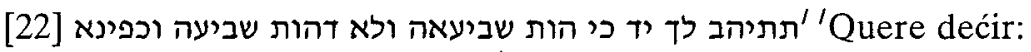
Da tu mano como si estuvieras 'harto y no como ha<n $>$ bierto y harto.

\section{[CONTINuACión de la SEMblanza DE BEN-SiRÁ]}

\section{[A.3. Los estudios de Ben-Sirá]}

${ }^{130 b}$ Y diǰeron por Ben-Sirá que en aquel año anỵeźó el séfer 'Torá entero; al segundo anyeźó mišné Torá, Talmud, ' halajot y hagadot; al trecero anyeźó dicduqué Torá y 'dicduqué soferim; al cuarto anỵeźó calot vaḥamurot, tecufot ${ }^{15}$ ugmatriaot; al quinto anyeźó hablas de mal'ajim y šedim 'y maźalot y de 'ofot y hayot; al seśeno anveźó Sifrá 'y Sifré, Taná de bet Eliyahu. No quis̀o [= quedó] cośa ni chica ni grande 'que no anỵeźó.

'Ven y verás la hojmá de Ben-Sirá, que le traían un kilón ${ }^{/ 10} \mathrm{de}$ trigo delantre y sabía cuántos trigos 'son y [= ni] [uno] más ni [tachado otro] uno manco.

\section{[A.4. Ben-Sirá y los sabios de Nabucodonosor]}

Hasta que lo oyó 'Nebujadneŝar, rey de Babel, y sus sabios y dećían: « Guay [de] 'mosotros!, agora mos matará el rey a todos por 'él. Para esto [vam]os [to]dos ande el rey y lo meteremos ${ }^{115} \mathrm{en}$ mal y lo matará y escapamo[s] de él. Le haćemos que 'demande una demanda y afilú que habla la vedrad, digamos 'que no [es] y lo mata ${ }^{16}$ y e[s]camos [= escapamos]". Y ansí [hi]ćieron.

Fueron 'los consejeros al rey y le dijeron:

-Demándale guay qué es 'y guayas qué es.

Luego mandó el rey por él mil ${ }^{120}$ caballeros que arancaban con sus manos árboles y alarćes. 'Diǰéronle:

-Señor, si mos mandas por gueras, hasta el 'cabo del mundo vamos; enpero delantre de este hajam 'no vamos.

Le escribió el rey una carta y les dio. 'Como vinieron le amostraron la carta a Ben-Sirá. Dijōo ${ }^{125}$ Ben-Sirá:

-No vos mandó por mí sino por mi taušán [] ${ }^{131 a}$ lućido. - Y tomó un taušán y le escribió: «Esta es la 'hayá del canpo que te sierva a ti”.

\footnotetext{
${ }^{16}$ Hasta aquí llega la edición de SCHWAB "Alphabets".
} 
Se ma[]iaron <se maraviaron [?]> de ver 'cómo la cabeza no con [fie]ro ni con ningún modo de cośa 'de las que linpian. Le mandó dećir con segundo askier:

15-Si no vienes por mi kabod, ven por kabod de tu taušán.

Luego 'se alevantó Ben-Sirá y s[e fu]e ande Nebujadneŝar. Luego 'se apaña[ron to]dos 1 [os] sabios y [fu]eron delantre 'de Nebujadneŝar y le enpezaron a demandar sus demandas. 'Dijéronle:

-Guay qué es y guayas qué es; y si no molo dićes ${ }^{1 / 0}$ te matamos.

Luego man[dó] y trujo un kafés de dos '[ka]tes y metió en[riba del ka]fés culebros, en el otro '[ka]t [a]lacranes. Diǰo:

-Que met[a uno] de vosotros la mano 'en el k[afés en el] kat de los culebros.

Puśo la mano, le 'morió el culeb[ro, di]j̆o "guay». Diǰo:

-Que p[o]nga un otro la ${ }^{15}$ mano en el kat de los alacra[nes].

Puś[o] la mano, dijo '"guayas". Respondió Ben-Sirá y dijo:

$-<\mathrm{Na}>$ guay y na guayas.

'Luego tenblaro[n] todos y se espantaron y [s]e echaron'de boca aḅajo. Díjoles el rey:

-Vosotros [d]iyisteš 'que si [no] vos respondía que lo matabaš. Agora ya vos ${ }^{120}$ respondió, que vos mate él a vosotro[s].

Los tomó Ben'-S[ir]á y los echó en el poźo de los leones y murieron.

Tomó '[el rey] a Ben-Sirá y lo asentó en su silla de oro. Díjole:

'-[Yo te] enreino po[r] rey.

Díjole:

-[Mi] señor, yo so chico y no '[so] para reino.

Díjole:

$-¿$ ¿Cuántos años tenes?

Díjole:

1131b-Siete.

Díjole el rey:

-Y Yoáš enreinó de siete años [cf. 2Reyes 12.1].

-Aquel 'era de źera' de David y no había [... o]tro que enreinara.

Díjole: 
'-Pos estate con mí aquí, que te [quero] demandar toda cośa 'que tengo safec que lo veo en el mundo y no lo sé lo que es.

${ }^{15}$ Díjole:

-Señor, tú demándame lo que queres y yo te responderé.

'Le demandó 22 demandas.

\section{[A.5. Las preguntas de Nabucodonosor a Ben-Sirá]}

$\left[1 .^{a}\right][$ Dí]jole:

-[El] taušán que me 'mandastes ¿con qué lo pel[a]s[tes]?

Díjole:

-[Con śe]rnic y c[al] 'viva, y ansí [hi]źo el rey Šelomó a malká [Sab]á que le vino 'toda llena de cabeos.

[2. $\left.{ }^{a}\right]$ Díjole:

-Si es vedrad que tú sabes ${ }^{110}$ tanto, dime: $i[$ en] mi güerta cu[ántos] árboles tengo?

Díjole:

'-Trenta modos tienes. Diez que s[u fruta] se come lo de adientro 'y lo de a[fu]era; y diez [que se c]ome lo de afuera y lo de 'adientro se echa; y [diez que] se c[om]e lo de adientro y [1o] 'de a[fuera se echa].

Díjole el rey:

-¿Queres ser [tú mi] yerno?, te daré ${ }^{115}$ a mi [hi]jja.

Díjole:

-No es cośa que pue[da] ser, porque yo so 'hombre [y] ¿cómo me ech[o con behemá]?, kemó šeneemar: Besar hamorim 'besaram [ $E z$ 23.20, 'Carne de asnos es su carne'].

$\left[3^{a}\right]^{17}$ [Como oyó] el rey que era meharef umgaḍef se ara[bió mu]ncho. 'Diǰo a sus hajamim:

-Anyeźa[me] una cośa, que quero matar '́a uno y [que] no lo sepa.

Diǰéronle:

\footnotetext{
${ }^{17}$ En la edición hebrea fijada por la imprenta no se indica dónde comienza cada pregunta; pero sí aparecen numeradas en la versión hebrea manuscrita $\mathrm{A}$ de la edición de YASSIF Ben Sira págs. 217-259. Atendiendo a tal partición, resulta que aquí faltan la núm. 3 (Yassif Ben Sira págs. 221-222) y, como en el texto hebreo impreso, la núm. 4 (YAssif Ben Sira págs. 222-225).
} 
-No sabemos.

Luego los ${ }^{120}$ mató. Le dijo a Ben-Sirá:

-Un amigo tenía y agora me 'salió enemigo y lo quero matar que no lo sepa. Dime tú 'cómo haré.

Entendió Ben-Siráa ${ }^{18}$ y le dijo:

-Tú asemejas 'al mašal del caballo [que] le dićen: Te quero cortar la ca[beza] 'y te daré [un] mo[... de] cebada.

Díjole:

-Por vida de [el] ${ }^{125}$ ídolo que no te mato, que me digas [...].

- Le das a que $[\ldots]$

\section{Glosario}

Requieren explicación las siguientes palabras, que recojo en orden alfabético:

acostar orejas 'atender, escuchar'

afilù (hb.) 'aunque'

alarćes 'arces'

álef (hb.): primera letra del alefato

'alilá (hb.) 'calumnia'

anyeźar 'aprender; enseñar'

apañarse 'reunirse'

arabiarse 'enfadarse'

asegas 'gavillas'

askier (tc. asker) 'ejército'

avidiguar 'revivir'

behemá (hb.) 'bestia'

berešit: vid. sidré

bet (hb.): segunda letra del alefato

calot vahamurot (hb. lit. 'ligeras y pesadas'): enseñanzas que resultan de aplicar las reglas del argumento a fortiori

dar y tomar 'comerciar, hacer negocios'

dicduqué: - soferim (hb.): normas no explícitas que se deducen de las formulaciones de los escribas; - Torá (hb.): normas no explícitas que se deducen de las formulaciones de la ley 'edut (hb.) 'testimonio'

haber (hb.) 'amigo, compañero'

${ }^{18}$ Lo que entendió Ben-Sirá es que quería matarlo a él. 
hagiadot (hb.) 'leyendas'

hajam (pl. hajamim, hb.) 'sabio; maestro'

halajot (hb.) 'normas legales'

hanbierto 'hambriento'

harbado 'golpeado'

hayá (pl. hayot, hb.) 'animal'

hojmá (hb.) 'sabiduría, ciencia'

kabod (hb.) 'honor, respeto'

kafés (tc. kafes) 'jaula'

kat (pl. kates, tc.) 'piso, altura'

kemó seneemar (hb.) 'según está dicho', frase usual en la literatura

rabínica para introducir un versículo bíblico

kilón (tc. kile): medida de peso equivalente a 36 kilos y medio

ma asé (hb.) 'cuento, relato'

mal 'ajim (hb.) 'ángeles'

malká (hb.) 'reina'

mašal (hb.) 'cuento, parábola'

maźalot (hb.) 'suertes; signos del Zodíaco'

meharef umgadef (hb.): era - 'repudiaba y menospreciaba'

mišné Torá (hb.) 'Profetas y Escritos'

molo 'nos lo'

morió 'mordió'

$n a$ (tc.) 'he aqui'

'ofot (hb.) 'pájaros, aves'

quené (imp. de la raíz $q \cdot n \cdot h, \mathrm{hb}$.) 'adquiere, obtén'

querer (+ part.) 'hay que (+ inf.)'

rehoc (imp. de la raíz $r \cdot h \cdot c$, hb.) 'aléjate'

reš (hb.): vigésima letra del alefato

safec (hb.) 'duda'

šedim (hb.) 'diablos'

séfer Torá (hb. lit. 'libro o rollo de la Ley') 'Pentateuco'

šemá '(imp. de la raíz $\check{s} \cdot m \cdot$ ', hb.) 'escucha, oye'

šeneemar: vid. kemó

śernic (hb. ז'sarnij) 'arsénico'

sey 'se'

sidré berešit (hb.) 'el orden de la creación' (lit. '... del Génesis')

šin (hb.): vigésimo primera letra del alefato

so 'soy'

soferim: vid. dicduqué

taušán (tc. tavşan) 'liebre'

tav (hb.): vigésimo segunda y última letra del alefato 
tecufot ugmatriaot (hb.): períodos temporales y cómputos numéricos según los valores de las letras del alefato

ticné (imp. de la raíz $q \cdot n \cdot h, \mathrm{hb}$.) 'adquiere, obtén'

Torá: vid. dicduqué, mišné, séfer

umgadef: vid. meharef

vahamurot: vid. calot

ugmatriaot: vid. tecufot

źera' (hb.) 'estirpe, simiente'

$y$ tb. 'también'

Pasemos ahora a analizar el texto de este manuscrito (abrev. $\mathrm{mJ}$ ) a la luz de las versiones judeoespañolas impresas (abrev. J) ${ }^{19}$ y del original hebreo impreso (abrev. $\mathrm{H}$ ) y manuscrito en sus dos familias de versiones (abrev. $\mathrm{mA} \mathrm{y} \mathrm{mB}$, respectivamente) ${ }^{20}$.

\section{EL MANUSCRITO Y LAS VERSIONES JUDEOESPAÑOLAS IMPRESAS}

\section{A. ESTRUCTURA, PRESENTACIÓN Y TITULACIONES}

Por su estructura textual, las versiones judeoespañolas impresas responden al modelo establecido a partir de la edición hebrea de Amsterdam $1697^{21}$, en la cual aparece en primer lugar la (A) Semblanza (2a-18a) y después la (B) Alfabeta (18a-32a), a la inversa de lo que sucedía en las ediciones hebreas antiguas (Constantinopla 1519, Venecia 1544, Constantinopla 1580, Salónica 1593-1595, etc.). Frente a ello y como ya hemos visto, en mJ la (B) Alfabeta figura inusitadamente incrustada entre la segunda y tercera parte de la (A) Semblanza.

También resulta novedosa en relación con $\mathrm{J}$ la formulación en $\mathrm{mJ}$ de los consejos de Ben-Sirá al maestro (A.2), en los que para

\footnotetext{
${ }^{19}$ Uso la más antigua, de Constantinopla 1823 , de la que las posteriores no difieren de modo significativo; vid. al respecto Romero «Ben Sirá" pág. 182.

${ }^{20}$ En la comparación textual he usado los siguientes textos. Para la versión impresa, la arriba citada segunda edición de Venecia 1544 (fotocopia de la JNUL R51A1130), en la que la (B) Alfabeta ocupa las hs. 2a-16a y la (A) Semblanza las hs. $16 a-30 a$; en el ejemplar que manejo faltan las hs. $10-15$ y 25 , que suplo por la edición de STEInSCHENEIDER Alphabetum; en las hojas que mancan correspondientes a la Alfabeta tengo también en cuenta la lista de los proverbios arameos que figura en dicha edición de Venecia en $h$. $1 b$ y en la que en ocasiones aparecen formulaciones diferentes. Y para los manuscritos, en sus dos familias de versiones, la edición de Yassif Ben Sira págs. 197-293.

21 YASSIF Ben Sira págs. 40 y 188-190.
} 
que no se pierda la ordenación alefática se recurre al artificio de mantener en hebreo la primera palabra de cada uno (quené, rehoc, šemá y ticné).

Por lo que se refiere a los títulos de cada parte, en J la (A) Semblanza se titula Séfer Ben-Sirá (2a) -que sirve de título general del libro y de específico de su parte- y la (B) Alfabeta se denomina Ma asiyot de Ben-Sirá 'al pí hahidá (18a). Tales titulaciones corresponden sólo en parte a las de las ediciones hebreas antiguas ${ }^{22}$, en las que el libro ostenta el título general de Séfer Ben-Sirá, encontramos el epígrafe de Alfabeta de-Ben-Sirá precediendo a los proverbios arameos (B), y el de Alfabeta ahéret de-Ben-Sirá precediendo a la (A) Semblanza.

Ignoramos si en $\mathrm{mJ}$ la obra tenía algún título general o específico precediendo al texto, ya que falta el principio. Sí aparece titulada la (B) Alfabeta con el inusitado epígrafe de Alfabeta segunda de Ben-Sirá. Es posible que tal denominación de "segunda" venga motivada por aparecer esta parte insertada justamente detrás de los consejos de Ben-Sirá a su maestro (A.2), que también constituyen una serie alefática, la cual sería la "primera» en el concepto del manuscriba.

\section{B. El LÉXICO}

En cuanto al léxico, encontramos que mJ abunda más en hebraísmos, arameísmos y turquismos que $\mathrm{J}$.

He aquí algunos ejemplos de los primeros: haber (mJ 129a:8) por compañero (J 5b:23); sidré berešit (mJ 129a:13) por órdenes de berešit (J 5b:28-29); hojmá (mJ 130b:9) por cencia (J 6a:23); kabod (mJ 131a:5) por honra (J 7a:1); zera ${ }^{\circ}(\mathrm{mJ} 131 \mathrm{~b}: 2)$ por semen (J 7b:20); meharef umgadef (mJ 131b:17) por arepudián y menosprecián (J 9a:3-4); hajamim (mJ 131b:18) por sabios (J 9a:5). Asimismo en mJ (131b:16-18) el versículo de Ezequiel que se cita está sólo en hebreo en tanto que en J (9a:2) aparece sólo en traducción; y como ya hemos dicho, la primera palabra de los consejos de Ben-Sirá al maestro se mantiene en $\mathrm{mJ}$ en hebreo, mientras que en $\mathrm{J}$ se traducen perdiéndose aquí la secuencia alefática. Pero es en los proverbios arameos donde en $\mathrm{mJ}$ se da el caso de una mayor acumulación de texto no judeoespañol, ya que aquí se mantienen en esa lengua mientras que en $\mathbf{J}$ sólo se formulan en versión judeoespañola.

\footnotetext{
${ }^{22}$ Y ASSIF Ben Sira págs. 4-5.
} 
En los hebraísmos encontramos un error al reproducir $\mathrm{mJ}$ (131b:8) como malká Sabá el מלכת שבא del texto hebreo (21b:12); en este caso coincide $\mathrm{mJ}$ con $\mathrm{J}$ ( $8 \mathrm{a}: 2$ ), como si en judeoespañol se hubiera lexicalizado la expresión prescindiendo del estado constructo hebreo. De los errores en relación con el arameo nos ocupamos más adelante (4.B.2).

Por lo que se refiere a los turquismos, se prefiere la palabra turca a la hebraica, aramea o hispánica en casos como: taušán (mJ 130b:25) por arnébet (J 6b:22); askier (mJ 131a:4) por fonsado (J 6b:30); kafés (mJ 131a:10) por crustelín (J 7a:18, ar. crastelín) 'cesta', helenismo del arameo (gr. $\chi \alpha$ ' $\rho \tau \alpha \lambda$ os) paralelo al crastel del original (H 21a:8); y kates (mJ 131a:11) por bocas (J 7a:19).

\section{C. LA TRADUCCIÓN}

En cuanto al texto en sí, lo que en primer lugar llama la atención es la redacción libre de $\mathrm{mJ}$, en un judeoespañol fluido, frente a la traducción servil de $\mathbf{J}$, muy apegada al original hebreo y en el que la distorsión de la frase hace difícil en ocasiones la inmediata comprensión ${ }^{23}$. Veamos algunos ejemplos.

Al describirnos la rapidez de cálculo de Ben-Sirá (A.3), leemos en $H(20 a: 25-20 b: 1)$ :

בוא וראה כמה היתה חכמתו של בן סירא שהיו מביאין לו סאה של חטים והיה אומר להם: חשבו חטים של סאה זו ותמצח ותמאו בו כך וכך גרגרים בחשבון cuyo paralelo en $J$ (6a:23-27) es:

Ven y verás cuánta era su cencia de Ben-Sirá, que eran traentes a él una meśura de trigo y era dićién a ellos: «Contad los trigos de esta mesura y hallaredeš en él tantos y tantos granos por cuenta».

Frente a ello y en formulación más resumida, así dice en $\mathrm{mJ}$ (130b:9-11):

Ven y verás la hojmá de Ben-Sirá, que le traían un kilón de trigo delantre y sabía cuántos trigos son ni uno más ni uno manco.

Al explicarle Nabucodonosor a Ben-Sirá sus razones para rete-

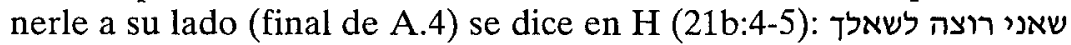
כל דבר שיש בלבי שאני רואה בעולם ואיני יודע, frase que se traduce en

${ }^{23}$ Vid. los comentarios al respecto en mi artículo Romero "Ben Sirán pág. 182. Allí caracterizo el texto judeoespañol impreso frente al hebreo (págs. 182-187). 
$\mathrm{J}(7 \mathrm{~b}: 20-22)$ : «que yo quero para demandar todo lo que en $\mathrm{mi}$ corazón que yo lo veo en el mundo y no lo sé», y en $\mathrm{mJ}$ (131b:3-4): "que te quero demandar toda cośa que tengo safec que lo veo en el mundo y no lo sé lo que es".

A tal propuesta del rey contesta Ben-Sirá en H (21b:5-6): אדוני כל מה שאתה רוצה שאל ואני אפרש לך כל מה שתאמר versión de J (7b:23-24) se formula: "Mi señor, todo lo que tú queres demanda y yo declararé a ti todo lo que dirás", y en la más libre de mJ (131b:5) es: «Señor, tú demándame lo que queres y yo te responderé».

Cuando Nabucodonosor invita a sus sabios a que le aconsejen cómo dar muerte a su enemigo, les dice en H (21b:6-7): הגידו לי דבר, que en J (9a:5) es: "Denuciad a mí cośa», y en mJ (131b:18): "Anveźame una cośa»; a lo que los sabios contestan en H (21b:78): אין אנו יודעין, en J (9a:8-9): «Non mośotros sabemos», y en mJ (131b:19): "No sabemos".

La libre formulación de mJ se deja sentir también en la traducción de los proverbios arameos de la Alfabeta. Baste un solo ejemplo. El prov. 20 se formula en $\mathbf{J}$ «Amor primero no tú niegues en él» y en $\mathrm{mJ}$ "Al amigo primero no niegues en él».

\section{EL MANUSCRITO JUDEOESPAÑOL Y LAS VERSIONES HEBREAS}

Pasemos ahora a comparar la versión de $\mathrm{mJ}$ con los textos hebreos impresos y manuscritos. Aunque el texto judeoespañol que estudiamos, al igual que las versiones impresas, corresponde a la familia del texto hebreo fijado por la imprenta, se advierten sin embargo entre uno y otro diferencias de interés.

Veamos por separado cada una de las dos partes de Los relatos de Ben-Sira: la Semblanza y la Alfabeta.

\section{A. LA SEMBLANZA}

En general, el texto de la Semblanza en mJ es más breve que el del original hebreo, yendo las omisiones desde palabras y frases hasta pasajes enteros.

\section{A.1. Omisiones}

De entre los pasajes omitidos sólo mencionaré los más significativos. 
Al final de la conversación con el maestro (A.2, 129a:13-15) resulta muy abreviada en $\mathrm{mJ}$ la explicación de cómo enseñó Jeremías a Baruj ben Neriyá y se omite el pasaje que le sigue sobre el estudio por Ben-Sirá del libro de Levítico, el aprendizaje de Jeremías y el comentario sobre Benayahu ben Yehoyadá $(\mathrm{H}$ $20 \mathrm{a}: 3 \mathrm{ss})$.

Han desaparecido asimismo de $\mathrm{mJ}$ las más o menos veladas amenazas de Ben-Sirá a los sabios de Nabucodonosor (A.4) en su comparecencia ante ellos (H 21a:2-8), la prueba de adivinación a la que Nabucodonosor somete a Ben-Sirá para que averigüe en qué escuadrón de entre varios se oculta el rey y la subsiguiente amenaza de Ben-Sirá al prepotente monarca de que será castigado por su soberbia (H 22a:8-22b:2).

Otros pasajes que resultan muy abreviados son el relato (A.5/1) de Salomón y el vello de la reina de Saba (H 21b:11-16/mJ 131b:8-9) y la historia (A.5/3) del caballo de Nimrod (H 22b:12-18 / mJ 131b:23-24). Asimismo en el pasaje de los árboles del jardín de Nabucodonosor (A.5/2) sólo se mencionan las características de los tres tipos de frutos, habiéndose omitido los nombres de los treinta árboles (diez por tipo) que los componen así como la mención de que fue Adán quien los trajo del Paraíso (H 21b:2a22a:8 / mJ 131b:11-14).

Algunas de tales omisiones dejan incompletas determinadas estructuras narrativas o eliminan elementos importantes en la narración, quedando el texto poco o nada comprensible.

Como ejemplo de las primeras mencionemos dos casos. En el episodio de los estudios de Ben-Sirá (A.3) ha desaparecido la precisión de לשנה שבעית 'el séptimo año' (H 20a:22), que debería figurar precediendo a la frase judeoespañola "No quedó cośa ni chica ...» (130b:6-7) y deja incompleta la serie de las siete etapas de los estudios. Igualmente en el pasaje de Ben-Sirá y los sabios de Nabucodonosor (A.4) no se precisa en mJ (131a:11-12) el número de culebras y alacranes que Ben-Sirá introduce en la jaula, los cuales en $\mathrm{H}$ son tres de cada clase (21:9).

Veamos algunos ejemplos de otras omisiones que afectan a la cabal comprensión del texto.

Los guerreros de Nabucodonosor (A.4) se excusan en H (20b:

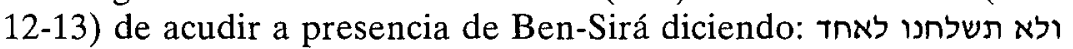

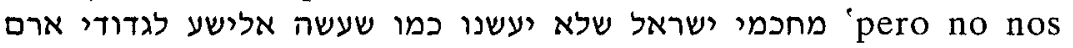


envíes ante uno de los sabios de Israel, no sea que nos haga lo que hizo Eliseo a los ejércitos de Aram', aludiendo al relato de 2 Reyes 6 en el que el profeta dejó ciegas a las huestes del rey sirio BenHadad. Nada de ello queda en la escueta formulación de mJ (130b:22-23) "enpero delantre de este hajam no vamos", de donde ha desaparecido la causa de la renuencia de los guerreros.

No se explicitan en mJ las palabras del mensaje que Nabucodonosor (A.4) envía a Ben-Sirá (H 20b:13-16): כתב להם: את חית השדה ] נתתי לו לעבדו ... אמרו לו סימן זה שהבטיחני אלהיי (A) escribió: Las bestias del campo se las he entregado para que le sirvan [Jer 27.6] ... Decidle esta señal que me prometió su Dios'. Con tales palabras Nabucodonosor pretende humillar a Ben-Sirá comparándolo con las bestias que Dios ha puesto a su servicio. En la formulación de $\mathrm{mJ}$, en el que el mensaje queda reducido a (130b:23) «Le escribió el rey una carta", cuyo contenido se desconoce, no se comprende la reacción posterior de Ben-Sirá, quien para burlarse le remite al rey una liebre, es decir, una bestia del campo.

Tampoco se entienden plenamente otras frases de $\mathrm{mJ}$. Tal sucede con (A.5/2) "Si es verdad que tú sabes tanto" (131b:9-10), por haberse omitido al final de la pregunta anterior la admiración de Nabucodonosor ante la sabiduría de Ben-Sirá y la afirmación de éste de que es profeta y Dios le descubre lo oculto (H 21b:1119). Y menos se entiende la segunda parte del consejo al maestro (A.2) que empieza con la letra $̌$ in, en la que la frase hebrea (H 19b:23-24) ואם ראית בחביריך דבר רע אל תוציא דבתן על לשוני (A has has visto en tus compañeros alguna cosa mala no propales su mala fama (lit. '... no hagas salir su mala fama') por tu lengua' queda reducida en mJ (129a:8-9) a "y alguna cośa mala no la quites por tu boca".

Algunas de tales omisiones dan lugar a una cierta reelaboración textual. Por ejemplo, en H (20b:23-24), cuando Ben-Sirá decide acudir a presencia del rey (A.4), se precisa (20b:23-24): וכשבא אליו אז היה בן שבע שנים 'Y cuando acudió ante él tenía entonces siete años'. La ausencia en $\mathrm{mJ}$ de la mención de la edad de Ben-Sirá (131a:6) obliga a que más adelante, cuando Nabucodonosor le propone hacerle rey y Ben-Sirá se excusa diciendo que es pequeño (H 21a:25 / mJ 131a:22-23), el rey haya de preguntarle: “¿Cuántos años tienes?" (mJ 131a:23). En este caso encontramos una cierta coincidencia, que supongo fortuita, entre $\mathrm{mJ}$ y las versiones hebreas manuscritas de la familia $\mathrm{mA}$, ya que en estas últimas la 
mención de la edad aparece dos veces: cuando Ben-Sirá se presenta ante el rey y cuando Nabucodonosor le propone convertirlo en rey ${ }^{24}$.

A veces lo que se produce es una reducción de motivos reiterados en varias frases del original. Tal es el caso, por ejemplo, de la conversación entre Ben-Sirá y Nabucodonosor (A.4) sobre la entronización del primero, en la que en $\mathrm{H}$ (21a:25-21b:3) se dice:

אדוני איני רוצה שאני קטון ולא ראוי לי שאמלוך על ישראל שאיני מזרע דוד דוד.

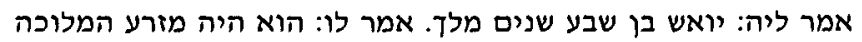

"Mi señor, no quiero, porque soy pequeño y no merezco reinar sobre Israel ya que no soy de la estirpe de David". Le dijo: "Yoáš a los siete años reinó". Le dijo: "Él era de estirpe real",

repitiéndose la mención de la estirpe, y que en mJ (131a:22131b:2) se convierte en:

«Mi señor, yo so chico y no so para reino» ... Díjole el rey: «Y Yoáš enreinó de siete años». "Aquel era de źera" de David ...".

\section{A.2. Formulaciones diferentes}

Entre los cambios más significativos hay que señalar las frecuentes diferencias de formulación que presenta mJ frente a $\mathbf{H}$.

A veces los cambios son el resultado de una sustitución léxica, como el de un indeterminado "ídolo" (A.5/3) en mJ (131b:25) en lugar del nombre de Kemóš de H (22b:19).

Pero en la mayoría de los casos se trata de formulaciones libres que pueden comunicar o no la misma idea del original hebreo.

Entre las primeras se encuentran casos como el arriba citado (3.C) de la rapidez de cálculo de Ben-Sirá, y otros varios. Así, en el consejo al maestro (A.2) correspondiente a la letra reš leemos en hebreo (H 19b:20-21) כי בעת עמדך לדין יעידו עליך 'cuando tengas que comparecer a juicio testimonien en tu favor', y en mJ (129a:56) "para que alguna vez si te alevantan alguna 'alilá, que den 'edut bueno por ti".

Cuando Ben-Sirá derrota a los sabios de Nabucodonosor (A.4), el rey les dice (H 21a:19-20) עתה חייבי' אתם בהריגה 'ahora vosotros sois reos de muerte' y en mJ (131a:20) "Agora ... que vos mate' él a vosotros".

Igualmente cuando el rey le explica a Ben-Sirá los motivos que

${ }^{24}$ Yassif Ben Sira págs. 215 y 216. 
tiene para eliminar a un supuesto enemigo (A.5/3), dice en $\mathrm{H}$ (22b:10) ואני שונאו 'y yo le odio' y en mJ (131b:20-21) "y agora me salió enemigo".

Y también la frase hebrea (ibid.) אמשול לך משל (1) voy a poner un ejemplo' (H 22b:12) se traduce en J (131b:22-23) «Tú asemejas al mašal».

Pero también esas formulaciones libres pueden trasmitir una idea distinta de la del original hebreo.

Por ejemplo, la apódosis del consejo de Ben-Sirá al maestro (A.2) que comienza con la letra cof (H 19b:16-17) והרבה לך בנים ואפי' הם מאה 'y ten muchos hijos aunque sean cien' se convierte en "y muchiguarás hijos hajamim" (mJ 129a:1-2), en donde el tener hijos sabios parece ser la consecuencia de casarse con mujer buena.

Igualmente en el consejo al maestro (A.2) que comienza con la letra sin se dice en H (19b:22-23) שב לך אדוני מעשות מריבה עם שכניך 'abstente (lit. 'vuélvete'), mi señor, de pelearte con tus vecinos', en tanto que en $\mathrm{mJ}(129 \mathrm{a}: 8)$ leemos "y sey honesto a tu haber".

Asimismo las cosas que aprendió Ben-Sirá el quinto año de sus estudios (A.3) son en H (20a:20-21) שיחת דקלי' ושיחת מלאכי השרת שלים ושיחת שדים ומשלות שועלים ángeles del Servicio y hablas de diablos y fábulas de zorros', que en $\mathrm{mJ}$ se convierten en (130b:5-6) «hablas de mal'ajim y šedim y maźalot y de 'ofot y hayot", donde los ('fábulas de zorros') se han trocado en maźalot, que en un principio podría pensarse que se trata de 'conocimientos astrológicos', pero que no creo que así lo haya entendido el adaptador sefardí, quien ha incluido tal palabra en medio de una serie que depende de hablas $d e$-entre los precedentes ángeles y diablos y los posteriores 'aves y bestias' - como si se tratara de algún ente potencialmente parlante. El cambio más bien parece el resultado de la reelaboración, en este caso no muy bien lograda, de una frase que el adaptador sefardí no ha entendido, en la que se ha sustituido משלות mišlot por el gráficamente próximo maźalot (מזלות) y ha quedado un rastro de los שועלים ('zorros') en las "ofot y hayot" ('aves y bestias').

En algún caso se dan cambios de formulación como resultado de diferentes cortes sintácticos. Así, por ejemplo, en el consejo (A.2) correspondiente a la letra tav leemos en el original hebreo 
(H 20a:1) תקנה לך זהובים וכל ממון ולא תגיד לאשתך 'Procúrate ducados y todo tipo de dinero y no digas a tu mujer ...'; y en mJ (129a:10) "Ticné a ti ducados. Si tienes munchos ducados no se lo digas a tu mujer».

\section{A.3. Rastro de motivos omitidos}

Además del ya comentado ejemplo de las fábulas de zorros (4.A.2), encontramos otros casos en que nos llegan rastros de motivos desaparecidos.

Los sabios de Nabucodonosor expresan su admiración al ver cómo Ben-Sirá ha escrito su mensaje sobre la cabeza de la liebre (A.4) diciendo (H 20b:19): ¿Cómo este pelo está afeitado como un pergamino?'; en tanto que en mJ (131a:2-4) leemos en formulación no muy lograda: «Se maraviaron de ver cómo la cabeza no con fiero ni con ningún modo de cośa de las que linpian". La frase judeoespañola -que por otra parte no alude al pelo ni al pelado- ha dejado una cierta compensación del afeitado en la fórmula "cośa de las que linpian".

\section{A.4. Adiciones}

Podemos también encontrar adiciones al original hebreo. Como es el caso del pasaje arriba citado (4.A.1) sobre la entronización de Yoáś, en que Ben-Sirá argumenta en H (21b:2-3): הוא היה מזרע המלוכה "aquel era de źera' de David y no había otro que enreinara».

Y los valientes caballeros de Nabucodonosor (A.4) le contestan al rey en H (20b:11): אם תרצה לשגרנו בכל העולם נלך 'Si quieres enviarnos por todo el mundo, iremos'; mientras que en mJ se añade (130b:21-22): "Si mos mandas por gueras, hasta el cabo del mundo iremos".

Algunas de tales adiciones las podemos considerar gratuitas, ya que no contribuyen a un mejor entendimiento del texto.

Como, por ejemplo, la frase antes citada (4.A.2 supra) del consejo (A.2) correspondiente a la letra tav que se concluye en el texto hebreo (20a:2) con אפילו היא טובה 'aunque sea buena', mientras que en mJ se dice (129a:11-12): “afilú que sabes que es muy hermośa y buena", sin que la palabra hermosa contribuya en nada a reafirmar las cualidades ahorrativas de la mujer.

Los caballeros que Nabucodonosor envía en busca de Ben-Sirá 
רוכבי סוסים כולם מקוטעי אצבע ועוקרי (A.4) son en H (20b:9-10) "caballeros todos ellos mutilados de un dedo y arrancadores de árboles'; y en mJ (130b:20) son "caballeros que arancaban con sus manos árboles y alarćes", sin que podamos precisar si el añadido "con sus manos" es un rastro del 'mutilados de un dedo', que ha desaparecido ${ }^{25}$.

Y la liebre de Ben-Sirá, a la que en la formulación del texto hebreo se alude como (120b:17-18) ארנבת אחד שיש לי 'una liebre que tengo', queda hermoseada en mJ cuando su dueño dice (130b:25-131a:1) «mi taušán [] lućido».

\section{B. LA Alfabeta}

Son también muchos los cambios que presenta la Alfabeta de nuestro manuscrito en relación con la versión hebrea.

\section{B.1. Estructura}

Hay que mencionar en primer lugar que su estructura difiere de la del original, en la que tras cada proverbio arameo y precedido de la fórmula fija לעולם לא rio más o menos amplio, que suele incluir relatos y cuentos a modo de ilustración.

Frente a ello, lo que encontramos en mJ son solamente los proverbios arameos y su traducción al judeoespañol, prescindiendo esta versión de todos los comentarios y relatos. Debemos suponer, sin embargo, que el autor sefardí del manuscrito sí conocía al menos algunos de tales relatos, pues tras la traducción del prov. 9 se añade: «Como el ma asé del que avidiguó al león», cuento que efectivamente aparece en $\mathrm{H}$ (7a:10-7b:22) en el comentario a tal

${ }^{25}$ Ambas circunstancias, mutilación de dedos y fortaleza para arrancar árboles, apuntan al valor de los emisarios. El pasaje está basado en el texto del midrás Lamentaciones Rabá II.4, donde al describir las fuerzas que Bar-Kojbá tenía en Betar durante el asedio de los ejércitos de Adriano, se dice:

Tenía [Bar-Kojbá] con él doscientos mil hombres con un dedo amputado [amputación a la que les sometía Bar-Kojbá para probar su valor]. Le enviaron los sabios un mensaje: “ ¿Hasta cuándo vas a seguir lisiando a los hombres de Israel?». Les contestó: “¿De qué otra manera se los puede probar?». Le contestaron: "Que al que no pueda arrancar un cedro del Líbano se le impida enrolarse en tu ejército». En seguida tuvo [Bar-Kojbá] doscientos mil hombres de cada clase.

Puede verse la traducción inglesa de A. CoHEn, en la serie del Midrash Rabbah, ed. H. Freedman et al., vol. VII (Londres 1939) págs. 158-159; otras fuentes y bibliografía en Yassif Ben Sira pág. 214 (6). 
proverbio y que trata de un hombre que revive a un león con una hierba maravillosa, y una vez vuelta a la vida, la fiera lo devora. Es interesante constatar aquí que tal cuento no figura, sin embargo, en las versiones judeoespañolas impresas.

En la Alfabeta de mJ tras cada proverbio arameo la traducción judeoespañola va introducida por la fórmula "quere dećir». No se atiene a esta estructura el número 7 , en el que tras la fórmula introductoria no se traduce el proverbio ("Arroja tu pan sobre la faz de las aguas y lo encontrarás al fin de los días') sino que se alude a su contenido y especialmente al amplio relato que en el original le sirve de explicación (H 4b:13ss).

\section{B.2. Los proverbios arameos}

Resultan interesantes las diferencias que encontramos en las formulaciones de los proverbios arameos entre $\mathrm{mJ}$ y el original. De los 22 proverbios, sólo 4 (núms. 1, 9-10 y 14) presentan un texto igual; los diferencias que encontramos en los restantes 18 pueden explicarse en $\mathrm{mJ}$ por diversas causas: errores gráficos, diferencias léxicas y permutaciones, omisiones y adiciones.

Son muy abundantes los casos de errores gráficos en $\mathrm{mJ}$ :

- שבתיא (prov. שביה (?descanse' (?) por 'abandónalo' (H 2b:7); וישוט (2) por que nade';

- (prov. 6) ליה 'de míl porl' (H 4a:3);

- ידעה (prov. 11) 'sabía' (masc.) poráa' (fem.) (H 9b:1);

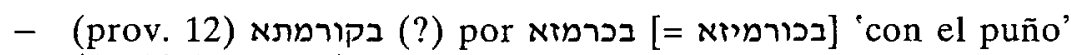
(H Alph. 10a:24);

- מבסרוה (prov. מבסרוהי 'los que la desprecian' (?) por que le desprecian' (H Alph. 10b:18);

- (prov. 16) אפרין 'cenizas' por (16) 'mañanas' (H Alph. 13a:15);

- מן לוק][ (prov. 17) ...' (?) por מחלוקת 'pelea, discusión' (H Alph. 13b:23);

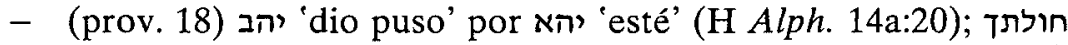
(?) por בולקד 'tu parte' (idem.); בה טבי" 'con ella buenos' (?) por בר טביין lit. 'hijo de buenos' (idem. 20-21);

- (prov. 20) כפר (?) 'niegues' (H Alph. 15a:16);

- תשבוק 'abandones' (H Alph. 15b:18). 
Encontramos varios casos de cambios gramaticales o de sustitución léxica:

- אסייא (prov. אסיא 'médicos' por 'm 2a:1);

- עולימא (prov. 4) עולימתא 'las jóvenes' joven' (H 3a:22);

- (prov. 5) (... הוי טב וחולקד 'sé bueno y tu parte ...' (H 4a:3) por הוי טב וידך (pé bueno y tu mano ...";

- לחכימא 'a los sabios' 'al sabio' (H Alph. 10a:24); y לשטייא 'a los necios' por לשטיא 'al necio' (idem.);

- ' (prov. 21) 'te multipliquen (den en profusión)' por יהון 'tienes' (H Alph. 15b:17).

Algunos de estos cambios provocan notorias faltas de concordancia. Así por ejemplo: (prov. 1) el plural אסייא no ha hecho cambiar el ליה 'de él' del final, donde esperaríamos להון 'de ellos'; y (prov. 4) a pesar del plural femenino עולימתא el verbo sigue en singular masculino צריך.

Podemos también señalar un caso de permutación de palabras, בפינא ושביעא 'hambrienta y harta' (H 16a:8-9) y en mJ שביעה וכפינא 'harta y hambrienta'.

No son muchas las omisiones, que pueden explicarse por incomprensión del texto. Así en el prov. 7, en el que tras 'aguas' no aparece en mJ el confuso וביבשתא / ויבשתא (H 4b:13 y $1 \mathrm{~b}: 8$, respectivamente) 'arroja tu pan al agua y (en) lo seco'; y en el 19, donde falta la segunda parte del no claro texto arameo (H Alph. 14b:18-19) 'y la lejana [se] come [a] su patrón'.

También encontramos ampliaciones del texto original. Algunas son menores, como en el prov. 4, en el que se repite el verbo צריך 'necesita (ser)' en la segunda parte del texto, el cual no aparece en $\mathrm{H}$ (3a:22). Otras son más significativas, tal es el caso del prov. 16 , con dos formulaciones distintas en el original, una más breve ערבא טבא H Alph. 13a:15) y otra más amplia (Hרבא טבא מאה צפרין (H 1b:18) 'Fianza buena cien mañanas

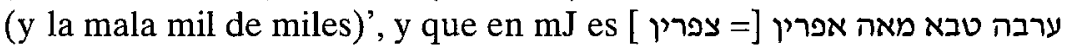
'Fianza buena cien mañanas, la mala mil mañanas y la mediana de una mañana a la otra mañana', ampliación de la que no he encontrado paralelo. 


\section{B.3. Las traducciones}

Son también interesantes las diferencias que en mJ presentan las traducciones de los proverbios arameos, tanto en relación con el original como con las formulaciones que se plasman en el propio $\mathrm{mJ}$, alteradas o modificadas por los errores y cambios indicados.

Traducciones de textos errados

Sorprendentemente, en la mayoría de los casos de errores gráficos en las palabras arameas, tales grafías anómalas no parecen influir en la traducción:

- שבקיה ('arrójalo') por en el prov. 2 la sustitución de ('descanse') no impide traducir acertadamente "échalo";

- en ואי לי לבישא 6 (lit. 'Ay de mí por el malo') se traduce correctamente por "Guay del malo";

- en 12 el inexistente בקורמתא se traduce "con palo" aproximándose al original 'con puño' (בכרמזא);

- en 16 el aquí imposible ('cenizas') se traduce correctamente por "mañanas" (צפרין);

- en 17 el errado [מן לוק no ha hecho olvidar el מחלוקת (disputa, pelea') original en la palabra "pelear»;

- en 18 el difícil בה טביין (lit. 'con ella buenos') se traduce acertadamente por «buenos";

- en מלכין ירבין לך 21 (lit. 'consejos te multipliquen') se vierte "consejos te dan", próximo al hebreo מליכין יהון לך (lit. "consejos tienes'); y לא תשבות (lit. 'no reposes') por "no deǰes de haćer", según el original לא תשבוק 'no abandones';

- y en 22 la ya aludida permutación en mJ de las palabras שביעה כפינא ('harto y hambriento') que rematan el proverbio ושביעא en H 16a:8-9) no impide que se traduzcan en su orden «hanbierto y harto».

Sin embargo, en alguna ocasión se suprime lo que no se ha entendido; así sucede en el prov. 2, en el que no se vierte el inexistente ויטוי que lo cierra. Y en otras los errores obligan a traducמבסרוה מiones ad sensum; como en el prov. 13, donde el errado 
se traduce por un neutro "al malo"; y en prov. 18 el imposible יהב חולתך se torna en "ajúntate».

Traducciones erradas de textos arameos no errados

También encontramos el fenómeno contrario, es decir, errores en la traducción de textos arameos correctos, sean o no iguales a las formulaciones originales. Así en el prov. 1 תצתרך 'lo necesitas' (en $2 .^{a}$ persona) se traduce por "haiga de menester" (en $3 .^{a}$ persona); en 6 lit. 'guay de aquellos que se juntan con él' se traduce en singular "y guay del que se apega con él»;

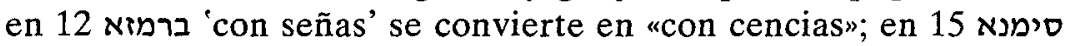
'señal' se traduce por «hallen»; en 19 el haber entendido 'la come' por "la como" (en 1.a persona) puede ser la causa de que el arameo קריבא סחורתא 'cercana la mercadería' se convierta en "cercana mi mercadería"; y en 21 los שתין 'sesenta' consejos se aumentan a "setenta".

No suelen tampoco reflejarse en las traducciones los cambios de plurales por singulares y de género femenino por masculino que los proverbios arameos de $\mathrm{mJ}$ presentan en relación con el texto original. Así los plurales שטייא y nכמייא, lit. 'médicos', 'sabios' y 'necios' de provs. 1 y 12 son respectivamente "médico", "sabio" y «loco"; y el inusitado y algo machista עולימתא lit. "las jóvenes' del prov. 4 es "el muchacho".

Especialmente mala es la traducción del prov. 22, obviamente no entendido y que, como algunos otros, presenta dos formulaciones paralelas en el original: תתיהב לך יד כי הות שביעא ולא דהות תe dé una mano que estuvo harta y no que estuvo

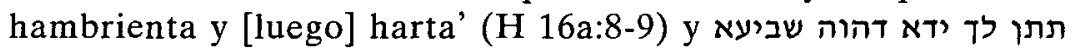
Te dé la mano que estuvo harta y [luego] hambrienta y no la de quien estuvo hambrienta y [luego] harta' (H 1b:24-25), cuyo sentido es que siempre es más generoso aquel que de siempre tuvo hacienda (y luego se empobreció) que el que era pobre y luego se enriqueció. La dificultad estriba en haber entendido el autor sefardí como "da tu mano" el arameo 'te dé una mano', lo que le obliga a traducir por una $2 .^{a}$ persona "estuvieras" la $3 .^{a}$ del original הות y a referir "hanbierto y harto" a un sujeto tú; la difícil traducción de por "como si» parece venir obligada por los errores indicados. 


\section{Traducciones libres}

Finalmente cabe aquí también señalar algunos casos que podemos considerar como traducciones libres. Así el בר דלא בר lit. "hijo que no es hijo' del prov. 2 (H 2b:7) se traduce por «hijo que no es bueno". La ampliación "con arte" del prov. 3 , inexistente en el

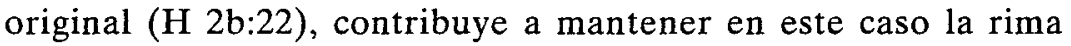
entre las dos partes de la frase. En 5 לא תמנע (H 4a:3) lit. "no apartes' es "no te vedes". En 8 se omite en la traducción de mJ el primer אכום 'negro', quizá llevado el copista sefardí por la formulación tradicional en judeoespañol del refrán ${ }^{26}$; cabe señalar, sin embargo, que con $\mathrm{mJ}$ coinciden en este caso los manuscritos hebreos ${ }^{27}$.

Resulta también más amplia que el texto arameo de $\mathrm{mJ}$ la traducción del prov. 10 (lit. 'tu mano no apartes del bien'), que se traduce como "tu mano no vedes de haćer bien a buenos". No responde a ninguna de las dos formulaciones arameas del original la traducción del prov. 17: פתור פתורא פריש מחלוקת 'Pon la mesa

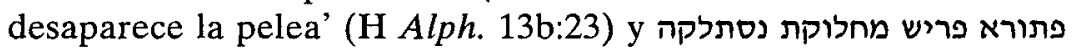
'Puesta la mesa la pelea desaparece' (H 1b:19), que en mJ es «Ves pelear, pon la meśa y se corta". Y asimismo resulta libre y ad sensum la traducción del prov. 21 ... שיתין מלכין ירבין לך ומלכות נפשיד (lit. 'Sesenta consejos te multipliquen y los consejos de tu alma ...) que se vierte por «Setenta consejos si te dan, el tuyo ...".

\section{CONCLUSIÓN}

A la vista de todo lo dicho, cabe concluir que la versión de $\mathrm{mJ}$ de Los relatos de Ben-Sirá nos ofrece un texto de redacción bastante libre, profundamente reelaborado textual y estructuralmente, en el que destaca la esencialización de los motivos y la omisión de elementos ocasionalmente redundantes.

Ante todo ello no podemos dejar de preguntarnos si no será esta la puesta por escrito de una reelaboración judeoespañola oral y tradicionalizada de la popular obra medieval hebrea de Los relatos de Ben-Sirá.

${ }^{26}$ L. Carracedo y E. Romero, "Refranes publicados por Ya'acob A. Yoná (edición concordada) y bibliografía del refranero sefardí", Estudios Sefardies 4 (= Sefarad 41, 1981) págs. 389-560: pág. 576 núm. 328.

${ }^{27}$ YAsSif Ben Sira pág. 267. 
Lo que sí podemos afirmar es que el texto que tenemos delante es ya el resultado de una copia manuscrita anterior. A ello apuntan numerosos datos. Así, por ejemplo, las tres correcciones del texto hechas por el propio manuscriba, dos de ellas tachadas y corregidas a continuación y una en corrección supralineal, probablemente fruto de lecturas apresuradas. Así en el prov. 16, en el que el copista leyó en un principio מאייוראליש mayorales rectificado después en el correcto מאנייאנאש mañanas; en la frase (130b:11) leída primero "ni otro (אוטר) manco" y rectificada en "ni uno (אונו) manco"; y en el hoy día borroso "se ma[]iaron" en cuya corrección supralineal parece leerse "se maraviaron" (131a:2).

Otras malas lecturas han quedado sin corregir: שינשייאש cencias por señas (prov. 12); ק quiśo por quedó (130b:7); y y por ni (130b:11). A ellas quizá debamos añadir el איין del prov. 15 que he leído hallen, lo cual deja sin sentido el texto y que quizá se trate de un error por " hay.

Pero sobre todo, lo que nos lleva a afirmar que el manuscrito que estudiamos es copia de otro anterior son los errores gráficos de los proverbios arameos y su escasa repercusión en las traducciones. Parece evidente que nuestro copista no sabía arameo y probablemente tampoco hebreo, de modo que al leer unos textos que no entendía, tuvo dificultades para reproducir correctamente su grafía. En efecto, los errores se producen principalmente por confundir letras que en la grafía manuscrita pueden tener un trazo

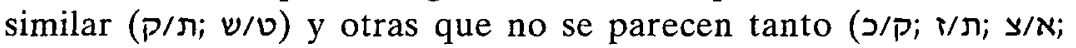
$ר / ה$; palabra.

Para terminar, quiero hacer alguna reflexión sobre la fecha del manuscrito que tenemos delante. En períodos más antiguos del desarrollo gráfico del judeoespañol se usaba un mismo signo ' $\lambda$ para representar no sólo -como en época tardía- la prepalatal africada sorda (hecho) y sonora (judió), sino también la prepalatal fricativa sonora (mujer) reemplazada luego por ' crito se ha producido ya la sustitución de ' $\lambda$ por ' $r$ para dicha prepalatal fricativa sonora, grafía que pasa a ser normativa a partir de finales del siglo XVIII. Por otra parte, no aparecen en el texto otros cambios que encontramos ya fijados a partir del primer cuarto del siglo XIX, y así se mantienen, por ejemplo, la libre alternancia entre 1 y " para representar la labial fricativa sonora 


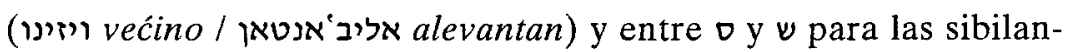
tes (אייוש ellos / דוקאדוס ducados).

Obviamente no podemos precisar si la actualización gráfica la llevó a cabo el copista de este manuscrito o si sólo se limitó a repetir un texto ya escrito así. Pero sí encontramos dos casos que nos confirman la existencia de un texto manuscrito anterior a este, de épocas en que aún no se había producido la mencionada distinción entre 'a y 'i para las prepalatales sonoras africada y fricativa: וי"ג וימיג'אש viejo (prov. 15) asemejas (131b:22), en donde a tenor de las restantes grafías del texto habríamos

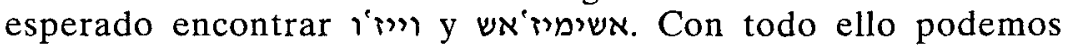
determinar con un razonable margen de error que el presente manuscrito se copió hacia finales del siglo XVIII o principios del $\mathrm{XIX}$, sin que podamos determinar la fecha del que le precediera.

Por ser de interés quiero recordar que la primera versión impresa que conocemos del texto judeoespañol de Los relatos de Ben-Sirá, si bien vio la luz en Constantinopla 1823, su texto, según mencionaba en mi artículo arriba citado ${ }^{28}$, está basado en otro anterior impreso o manuscrito. Ello quiere decir que por la misma época coexistieron versiones judeoespañolas muy diferentes de Los relatos de Ben-Sirá, hasta que el texto y al igual que había sucedido con las versiones hebreas, quedó finalmente fijado por la impresión de 1823.

${ }^{28}$ Vid. ROMERo “Ben Sirá” pág. 181. 


\section{RESUMEN}

En el presente artículo se lleva a cabo la edición de un manuscrito judeoespañol procedente de la Guenizá de El Cairo que contiene una versión fragmentaria de la obra medieval hebrea Los relatos de Ben-Sirá, comúnmente denominada Alfabeta de-Ben-Sirá o Séfer Ben-Sirá. El texto se analiza a la luz de las versiones judeoespañolas impresas y de las hebreas impresas y manuscritas.

\section{SUMMARY}

This article includes the edition of a Judeo-Spanish manuscript from the Cairo Geniza. The text is a fragmentary version of the medieval Hebrew prose work, The Tales of Ben-Sira (Alfabeta de-Ben-Sira or Sefer Ben-Sira). The editor analyzes and compares this text with Judeo-Spanish and Hebrew printed-edition readings of the same work, as well as with manuscript versions. 